\title{
ПАМЯТИ \\ ГАЛИНЫ АЛЕКСАНДРОВНЫ ПУЖЛЯКОВОЙ
}

Второго апреля 2006 г. безвременно, после тяжелой продолжительной болезни ушла из жизни доцент кафедры метеорологии и климатологии географического факультета Саратовского государственного университета, кандидат географических наук Галина Александровна Пужлякова.

Г.А Пужлякова родилась 14 марта 1947 года. В 1970 г. она с отличием окончила географический факультет по специальности «Метеорология».

По распределению была оставлена на кафедре метеорологии и климатологии, где работала до своей кончины сначала в должности старшего лаборанта (с сентября 1970 по 1979 г.), затем в октябре 1979 г. она была избрана на должность ассистента этой же кафедры, с января 1988 г. работала в должности старшего преподавателя, в июне 1990 г. была избрана на должность доцента.

За время работы в университете Г.А. Пужлякова проявила себя высококвалифицированным преподавателем высшей школы. Ею разработаны и читались лекции по курсам «Синоптическая метеорология», «Климатология», «Статистические методы краткосрочного прогноза погоды». По этим же курсам она вела практические занятия. Она читала также лекции по курсам «Теория общей циркуляции атмосферы и климата», «Вопросы изменения климата», руководила учебной практикой по метеорологии, а также курсовыми и дипломными работами, являлась членом ГАК. Выполнявшаяся ею педагогическая работа велась на современном научном и методическом уровне. Галина Александровна быстро выдвинулась в число ведущих доцентов кафедры. Научные интересы Г.А. Пужляковой были связаны с региональной синоптикой и экологией современного города. В марте 1989 г. на заседании специализированного Совета в Ленинградском гидрометеорологическом институте она защитила кандидатскую диссертацию «Исследование синоптических процессов Южного Предуралья применительно к задачам метеорологических прогнозов». Ею написаны 5 разделов в монографиях «Климат Саратова», «Метеорологические аспекты загрязнения воздуха в Саратове», а также «Руководстве по краткосрочным прогнозам погоды» (ч. II, вып. 1). Всего ею было опубликовано более 50 научных работ, в том числе 3 учебно-методических пособия. Она принимала участие в 14 научных конференциях международного, всероссийского и регионального масштабов. Принимала активное участие в госбюджетных хоздоговорных НИР, а также являлась исполнителем НИР по двум грантам программы «Университеты России» (1998-2001 гг., и 2002-2003 гг.) и в рамках НИР по единому заказу-наряду Минобразования России «Крупные города как природно-техногенные системы» (2001-2005 гг.).

Г.А. Пужлякова относилась с большой ответственностью к повышению своей профессиональной квалификации: в 1986 г. закончила без отрыва от производства курсы по вычислительной технике и программированию, в 1988 г. прошла обучение на факультете повышения квалификации при Ленинградском гидрометинституте. В 1994 г. Пужляковой присвоено ученое звание доцента по кафедре метеорологии и климатологии.

Г.А. Пужлякова всегда была активным общественником. Многие годы она являлась профоргом кафедры, за что награждена знаком « За активную работу в профгруппе» (1980 г.), в течение ряда лет была председателем учебно-производственной комиссии при профбюро географического факультета, референтом Зональной научной библиотеки Саратовского государственного университета им. В.А. Артисевич по метеорологии, представителем профбюро в ученом совете факультета, куратором студенческой группы. В 1992 г. она участвовала в проведении научно-общественной экспертизы четвертого энергоблока Балаковской АЭС.

Г.А. Пужлякова всегда отличалась дисциплинированностью, большой требовательностью к себе, серьезным отношением к выполняемым обязанностям, корректностью в отношениях со студентами и сотрудниками. Она многократно отмечалась благодарностями, почетными грамотами университета, была награждена почетной грамотой Минобразования России, имела звание «Ветеран труда».

В последние годы Галина Александровна была заместителем председателя Государственной аттестационной и экзаменационной комиссии, организовывала и проводила госэкзамены по специальности. Г.А. Пужлякова - бессменный участник празднований Всемирного дня метеоролога, организатор и член жюри олимпиад.

Г.А. Пужлякова оставила яркий след в истории кафедры метеорологии и климатологии и географического факультета. Светлая память об этом скромном, обаятельном человеке, настоящем товарище и друге, бескорыстном труженике высшей школы останется в сердцах всех, кто с ней работал и общался.

Ю.А. Скляров, Е.А. Полянская, С.Н.Лапина, Л.И. Фетисова 